F. Child Lang. 32 (2005), I-34. (C) 2005 Cambridge University Press

DOI: I0.1017/So305000904006592 Printed in the United Kingdom

\title{
The relationship between prosodic and syntactic organization in early multiword speech*
}

\author{
HEIKE BEHRENS \\ Rijksuniversiteit, Groningen \\ AND \\ ULRIKE GU'T \\ Albert-Ludwigs-Universität, Freiburg \\ (Received I7 April 200I. Revised 8 March 2004)
}

\section{ABSTRACT}

Several descriptions of the transition from single to multiword utterances use prosody as an important diagnostic criterion. For example, in contrast to successive single-word utterances, 'real' two-word utterances are supposed to be characterized by a unifying intonation contour and a lack of an intervening pause. Research on the acquisition of prosody, however, revealed that control of the phonetic parameters pitch, loudness, and duration is far from complete at such an early stage. In this study, we examine the interaction between the development of different types of syntactic structures and their prosodic organization. Data from a detailed production record of a monolingual German-learning boy is analysed both auditorily and acoustically with a focus on four different types of two-word utterances produced between 2;0 and 2;3. Two major findings are reported here. First, the different types of two-word utterances undergo individual trajectories of prosodic (re-)organization, in part depending on the time course in which they become productive. This suggests that different types of

[*] The data collection and research was carried out at the Max Planck Institute for Evolutionary Anthropology in Leipzig, which also provided a stimulating environment for working on our ideas. We are grateful to several transcribers, most notably Solvejg Kühnert, Jana Jurkat, and Susanne Mauritz for their indispensable groundwork in transcribing the data, and to Anne Alexander for her help in the acoustic analyses of a part of the data. Of course, none of this would have been possible without the continuous good spirit of Leo and his parents. We would like to thank the audience at the International Association for Child Language (IASCL) in Madison/Wisconsin, July 2002 for their helpful comments and suggestions. Address for correspondence: Heike Behrens, Afdeling Duitse Taal en Cultuur, Rijksuniversiteit Groningen, Postbus 7I6, 9700 AS Groningen, The Netherlands. e-mail: h.behrens@let.rug.nl 
multiword utterances become prosodically fluent at different points in time. Second, the variability of prosodic features such as pauses and stress pattern is very high at the onset of combinatorial speech. Consequently, fluency or disfluency of individual examples should not be used as a reliable criterion for their syntactic status and we recommend caution when taking prosody as a cue for syntactic development.

\section{INTRODUCTION}

When children acquire their first language, they have to learn how to encode their intentions syntactically and semantically. In addition, one of their phonological tasks is to learn how to organize their speech prosodically. So far, these two aspects of language acquisition have been studied independently and consequently we know only very little about how children's structural and conceptual organization of language relates to its prosodic organization. This paper focuses on the relationship between a German child's prosodic and syntactic development in early multiword speech. In particular, we investigate the reliability of prosodic features in early multiword constructions, given that previous studies provided controversial and inconclusive evidence.

Previous research on the acquisition of grammatical relations in early multiword speech revealed that children's first two-word utterances consist of strings of words rather than syntactic constructions in which the relationship between the words is encoded grammatically. If these words refer to the same topic, one needs to apply 'rich interpretation' to resolve the syntactic relationship between them (Bloom, i970). For example, noun-noun combinations like Mommy sock can encode multiple utterance meanings that go beyond the semantics of the individual words, such as possessor-possessed relationships as in Mommy's sock or subject-object relationship as in Mommy puts my sock on (Bloom, I970: I3f.).

Research on the acquisition of word combinations has relied on prosodic features as cues for syntactic and semantic relations. In particular, the intonation contour, the length of pauses between words, and the duration of words or syllables are analysed (e.g. Bloom, I973; Branigan, I979; Scollon, I979; Crystal, ı 986; Veneziano, Sinclair \& Berthoud, I990; Tracy, I99I; D'Odorico \& Carubbi, 2003). However, the criteria that are applied vary considerably. Moreover, one needs to take into account that word and sentence prosody are not yet fully acquired at the onset of combinatorial speech (e.g. Gut, 2000). In order to shed more light on the relationship between syntactic and prosodic organization in early combinatorial speech, this paper investigates the prosodic development of four types of two-word utterances in a particularly detailed case study of a boy acquiring German. 


\section{The semantic and syntactic structure of early word combinations}

According to some analyses, multiword utterances are acquired in two phases: a transitional phase, in which two single-word utterances are in close temporal proximity, and the two-word phase proper, in which two words are combined into a single utterance (Scollon, I979; Crystal, I986; Veneziano et al., I990). Following Bloom (1973), two-word utterances of the transitional phase have been called Successive Single Word Utterances (SSWUs). The difference between single-word utterances and SSWUs lies in the assumption that the latter form a semantic and pragmatic unit because the two words elaborate on a single topic. In Bloom's terms, SSWUs are 'occurrence[s] of single words in succession that are not conjoined, within the bounds of a single speech event, that is, single-word utterances that share topic and context' (Bloom, I973: 32). D'Odorico \& Carubbi (2003: I08) found that word combinations with a semantic relationship, that is combinations in which the meaning of the utterance as a whole is different from the meaning of the two words separately, begin to be produced at the roo-word level. In this phase, supposedly only one word carries the illocutionary force of the utterance so that the other word would be uninformative in isolation (e.g. not in not broken). Word combinations with two content words of equal semantic weight (e.g. chair mummy or throw ball) become frequent only at the 200-word level.

The two-word stage is marked by the transition from grammatically unrelated word combinations to utterances that show first signs of grammatical organization by consistent use of word order or inflection. Again, it is controversial how to characterize the relationship between the two words in the early, pre-grammatical stage, especially because utterances of different degrees of productivity and complexity co-exist. Braine (1963, I976) took a structuralist point of view in his analysis of the syntactic distribution in early child language. He claimed that early multiword utterances can be classified as a set of positional patterns (the so-called pivot grammar). However, it turned out that positional patterns alone did not suffice to determine the difference in structural relationships between the words. Consequently, the insufficiency of positional criteria led to alternative classifications of child language by semantic and/or prosodic criteria. Bloom (I970, I973) proposed that SSWUs constitute a syntactic basis for multiword utterances. Their word order is variable and does not seem to follow pragmatic factors like 'topic-comment' information structuring where the given information precedes the new information, but can best be analysed in terms of a restricted set of semantic relations like 'possessor-possessed' (Bloom, i 973: 45ff. and i i 7 ff.).

In the next developmental phase, multiword combinations show a stabilization of word order and grammatical integration, e.g. several words 
form part of a noun phrase (green duck) rather than being separate as in duck | green (where '|' stands for a pause). These stages are not discrete but transitional, which means that structures without or with only rudimentary encoding of their syntactic relationship are still produced while more advanced structures emerge.

This review shows that children's first word combinations are most commonly classified by their meaning, e.g. as 'semantic units' (Crystal, I 986 ; Kaltenbacher, I 990), 'pragmatic units’ (D’Odorico \& Carubbi, 2003) or as 'referring to the same topic' (Bloom, I973). The syntactic relationship between these words is not encoded and open to interpretation, and their prosodic integration has not yet taken place, as will be shown in the next section.

\section{The prosodic structure of early word combinations}

Research on early word combinations makes use of prosodic features of utterances such as pauses, stress, intonation, and duration in order to characterize developmental phases. The following prosodic features are used to define SSWUs: both words are stressed, and typically each word shows a word-final falling pitch. Moreover, the two words tend to be separated by a pause. Conversely, two-word utterances are usually taken to have a distinctive stress pattern, an integrated intonation contour and no separation by a pause (Bloom, I973; Rodgon, I 976; Scollon, I979; Crystal, I986; Kaltenbacher, I990; Tracy, I 991). Several studies based on acoustic measurements observed that the prosodic features interact in a complex fashion in child speech (e.g. Kaltenbacher, I990; Pollock, Brammer \& Hageman, I993; Gut, 2000). The results of studies on the relationship between early multiword speech and its prosodic form can be summarized as follows :

\section{Pauses}

As described above, pauses are usually taken to differentiate between SSWUs and two-word utterances. In his analysis of early sequences of words, Scollon (1979: 219) distinguishes between vertical constructions and horizontal constructions. Vertical constructions consist of individual words that are linked by 'a definite semantic connection' and that are broken up by pauses (e.g. Ron | talk). Horizontal constructions occur later in development. Here, semantically related words appear without an intervening pause.

Measurements of the correlation of pause length and utterance type, however, seem somewhat arbitrary: Branigan (1979) classifies utterances with an intervening pause between 400 and I I00 milliseconds as SSWUs and utterances with an intervening pause between I 00 and 400 milliseconds 
as two-word utterances. In contrast, Veneziano \& Sinclair (2000) have a similar criterion for two-word utterances (a pause of less than 500 milliseconds) but include utterances with a pause of up to two seconds as SSWUs. Finally, Kaltenbacher ( 1990 ) considers strings with a pause length of up to I 200 milliseconds as two-word utterances.

Moreover, research on pauses in child language showed that children initially cannot control pause length. In early word combinations, pauses do not systematically structure speech in a linguistically meaningful way. Rather, the insertion of pauses seems to be arbitrary and governed by limits of children's speech-processing capacity (Branigan, I979; Scollon, I979; Gut, 2000). In a study of bilingual children, the systematic use of pauses was first observed from 3;5 onwards (Gut, 2000). Only then did pauses separate both syntactic and semantic units of speech. For example, contrastive statements like $I$ do this | and you do that were structured in this way and pauses separated subordinate structures from main clauses.

\section{Stress}

Research on the acquisition of stress patterns in early word combinations is virtually non-existent. Based on impressionistic observations, Crystal ( 1986 ) suggested that stress differentiates types of early word combinations. He claimed that SSWUs consist of two words with equal stress, while in two-word utterances one word carries greater stress than the other. In $90 \%$ of the cases this is the second word. The acquisition of word stress is well documented and researchers have drawn attention to metrical restrictions for stress patterns of bisyllabic and multi-syllabic words. Roughly speaking, in languages like Dutch, German, and English, word stress develops from the production of only one syllable (e.g. ' $n a$ for banana) to a bisyllabic trochaic form, i.e. two syllables with a strong-weak structure ('nana for banana). This trochaic phase is followed by a phase where children produce multi-syllabic words with more than one stressed syllable. However, stressed syllables within a word are equally strong (i.e. level stress as in 'kinder'garden), i.e. the child does not differentiate between primary and secondary stress (e.g. Fikkert, I994; Archibald, I995; Fikkert, Penner \& Wyman, I998). From about 2;3 on word-stress patterns such as strong-weak-strong-weak are produced correctly with primary stress on one foot and secondary stress on the other as in 'kinder,garden (Fikkert et al., I 998).

From this follows that children produce their first word combinations before they have mastered the final stage of word stress, and while they are still in the phase of level stress production of iambic and multi-syllabic words. It is as of yet unknown how the metric templates found in multisyllabic words relate to the prosody of multiword utterances. 
The production of stress in early combinatorial speech is also constrained by physical abilities. In German and English, stress is usually produced by an increase of pitch height (the fundamental frequency), loudness (the intensity), and by increased vowel and syllable duration. Pollock et al. (I993) showed that stress production by two-year-olds is very variable. They measured the peak pitch and intensity on stressed and unstressed syllables of ' $C V C V$ and $C V$ ' $C V$ words. Whereas three- and four-year-olds consistently used higher pitch and increased intensity on the first and the third syllable in these words respectively, two-year-olds did not show any systematic use of these acoustic parameters. Pitch and intensity were not significantly higher in stressed syllables than in unstressed syllables. In other words, young children had no productive command of stress. This finding is supported by Kehoe, Stoel-Gammon \& Buder (I 995), who found that children aged $\mathrm{I} ; 6$ use intensity to mark stress significantly less than children aged $2 ; 6$ and adults.

\section{Intonation}

The term 'intonation' refers to pitch movement across an utterance or a sequence of words. In child-language research, intonation is often used to distinguish different utterance types. It has been claimed that the phase of word combinations is reached when two words begin to be integrated into a single intonation unit. SSWUs, conversely, are characterized by the intonation contour of two separate single-word utterances (Bloom, I973; Dore, I 975 ; Scollon, I979; Wijnen, I990; D’Odorico \& Carubbi, 2003). Branigan (r979), however, showed that there is no difference between SSWUs and two-word utterances with respect to pitch movement. In his investigation of three English-speaking children he found that the first words of SSWUs do not end in a significantly higher pitch than words in single-word utterances or than the final words of word combinations. Moreover, the pitch height at the end of the first words of both SSWUs and multiword utterances is very similar. Branigan (I 979) therefore concludes that there is no difference between SSWUs and multiword utterances in terms of semantic content, syntactic structure or speech planning; they are simply characterized by immature (prosodic) articulation.

Regarding distinctive pitch movements, several studies on the acquisition of intonation demonstrated that individual children use the pitch movements rise and fall systematically for the differentiation of such basic types of speech acts as questions and statements (e.g. Halliday, I975; Furrow, I984; Galligan, I987; Bassano \& Mendes Maillochon, I994; Gut, 2000). Others failed to find any systematic use of pitch movements (Marcos, I 987; Robb \& Saxman, I989; Flax, Lahey, Harris \& Boothroyd, I991). 


\section{Duration}

Duration describes the length of linguistic units such as words or syllables, and has been used to measure differences between SSWUs and word combinations. Several authors report final-syllable lengthening, a characteristic of adult speech, as early as the babbling phase (Laufer, I980; Robb \& Saxman, I989; Snow, r 994) but assume that this is as yet devoid of linguistic purpose. Systematic use of final-syllable lengthening in falling pitch movements was reported by Kubaska \& Keating (I98I), Pollock et al. (I 993), and Snow (I 994). Conversely, neither Gut (2000) nor D'Odorico \& Carubbi (2003) found systematic final-syllable lengthening in the early combinatorial speech of their Italian and German/English bilingual subjects up to $2 ; 5$. Branigan ( 1979 ) reports that non-final words in both SSWUs and word combinations are compressed to a similar extent and concludes that they cannot be distinguished on the basis of duration.

The results of these studies on the relationship between prosodic and syntactic relationships reflect a variety of methodological approaches in search of reliable prosodic correlates of syntactic units. However, the attempt to identify syntactic units by their prosody is problematic because of the underlying assumption that all aspects of prosody are already mastered and controlled perfectly at the time of the first word combinations. Several studies on the phonetics and prosody of child speech show that this is not the case (e.g. Pollock et al., I 993; Gut, 2000). In conclusion, it is very important that one does not simply take prosodic aspects of early combinatorial speech as a reflection of their semantic and/or syntactic status. Rather, it has to be kept in mind that the child is in the process of acquiring the prosody of a language as well as its syntax. Therefore, our study explores the development of prosodic integration in four particular types of multiword utterances in more detail.

\section{Rationale of this study}

Previous studies analysed different kinds of multiword utterances and tried to relate the degree of semantic cohesion or type of syntactic structure between the words to the prosodic properties of the utterance. This entailed the problem of rich interpretation (i.e. the listener's judgement about the meaning and underlying syntactic relationship between the words), as well as possible circularity. The perception of semantic coherence or assignment of a particular syntactic structure might be influenced by the prosodic fluency of the utterance and vice versa. In our study we try to avoid the problem of rich interpretation. Instead, we trace the prosodic development of four distinct types of two-word utterances across a three-month period. That is, we compare the prosodic development of Noun + Infinitive constructions with that of early Noun + Particle and Determiner + Noun 
constructions (for details see below), and in addition compare these word combinations to Noun + Noun repetitions. The analyses are based on an extensive longitudinal record of one monolingual child acquiring German. Our three-month investigation period covers the development from the earliest and rather disfluent word combinations to fluent ones. By looking at different types of word combinations with different syntactic constituency we investigate whether the development of fluency is a uniform process across all types of constructions or whether different types of word combinations show different developmental patterns.

Auditive analyses and acoustic measures of the prosodic structure were carried out in order to (a) determine whether the different types of twoword utterances show the same prosodic properties and developmental trajectories, and (b) to analyse the variability of prosodic features in order to be able to estimate how stable and reliable they are across development.

\section{METHOD}

\section{Participant and sampling}

The participant of this study is a monolingual German boy, Leo, who is growing up in Leipzig, Germany. Both parents have a higher education (his father is an academic, his mother a trained bookseller) and speak dialect-free, clearly articulated standard High German. The boy's language development was recorded from I ; I I.I 3 , the onset of multiword speech, up to $5 ; 0$.

The record of Leo's language development is special because of its recording density (five hours per week), and the combination of parental diaries with audio- and video-recordings. Of relevance here are the first three months of Leo's multiword productions, i.e. the period between 2;0 and $2 ; 3$. During this period, the mother was the primary caretaker of the child, and was paid as a full-time research assistant for taking the diary notes and making the audio recordings. Two weeks before his second birthday, Leo's parents completed a vocabulary checklist modelled after the CDI for English (Fenson, Dale, Reznick, Thal, Bates, Hartung, Pethick \& Reilly, I993) since a German CDI did not exist at the time. For the following two weeks, the parents practised taking the diary notes on the newest and most complex utterances. Diary notes were spoken into a dictaphone at the time and place of the action to avoid misrepresentation by having to memorize.

Between 2; 0 and 3; 0 , the daily parental diaries were augmented by five one-hour audio-recordings a week (once a week, a video-recording was made in addition to the audio-recordings). The sessions were recorded with a Sony Minidisc recorder MZ-R 35 using two wireless and portable Shure 
BG4. I Unidirectional Condenser Microphones, and a Shure ETPD-NB Marcad Diversity Receiver. Each recording was digitized and transcribed in SONIC-Chat ( $c f$. MacWhinney, 2000) with transcription guidelines developed for German by the first author.

\section{Leo's language development in the investigation period}

The parental CDI and diary notes allow us to exactly determine the state of Leo's language development at the onset of our study. He produced his first word combination at I; I I.I3 with an active vocabulary of about 340 word forms. He also produced his first morphological contrast (a singularplural distinction) in the same week. This suggests that the appearance of multiword speech relates to vocabulary size as proposed by Bates \& Goodman (I999). They summarize findings that show that the size of active vocabulary correlates with grammatical complexity, such that grammatical development starts with a vocabulary size in the 200- to 300-word range. Compared to the data of English and Italian children presented in Bates \& Goodman (r999), Leo is a late talker and his vocabulary is relatively large before grammatical development sets in. By the time of the first recording analysed for the purposes of this study (at 2; O.I), Leo had produced 20 multiword combinations, i.e. combinations of different words which were perceived as meaningful word combinations by the parents. This means that our analyses capture the very onset of multiword speech. Apart from being able to combine different words, Leo also had a strong tendency to repeat individual words (e.g. Hunger Hunger 'hunger hunger') or even longer phrases. Since Leo was not a very clear articulator, repetitions might have helped him to improve his articulation and fluency, and to be understood by his interlocutors. He did not often produce filler syllables, although a few filler-type constructions did occur (see below).

From his second birthday onwards, Leo produced different types of multiword utterances with increasing frequency. Among these are imitations of various kinds, Noun + Noun combinations such as Glocken | Kirche 'bells | church' (2;0.I); and Adverb + Noun combinations such as da da da Frosch Frosch 'there there there frog frog' (2;0.I). This example again demonstrates Leo's tendency to repeat words or phrases, but also shows that he is able to produce long strings of words. Typically, however, his word combinations at 2;0 are limited to two-word utterances. By 2;3, more complex utterances are attested, e.g. utterances with finite verbs (I). But non-finite, infinitival utterances are still very common and account for about $50 \%$ of his main verb use (or $40 \%$ of all verb tokens including copulas and auxiliaries). Infinitives now also occur in utterances longer than two words (2). 

(I)
$2 ; 3.0$
Maus kocht Mittagessen
Bratkartoffeln.
'mouse cooks lunch
fried potatoes'
(describing the picture on his plate)
(2) 2;3.0 Elefant Loeffel geben.
'elephant spoon give-INFINITIVE'
(gives a spoon to the elephant; picture on same plate)

\section{Data}

We analysed the prosody of Leo's productions at four points in time within a three-month period after the first appearance of multiword combinations. We selected four types of two-word utterances which are attested at 2; 0 and continue to be produced throughout the three next months. These types are distinguished by the syntactic category of the words involved as well as by their word order (i.e. only examples with the same word order were selected like Noun + Infinitive but not Infinitive + Noun).
a. Noun + Noun repetitions:
Hunger Hunger 'hunger hunger'
b. Noun + Particle combinations:
Hut ab
'hat off'
c. Noun + Infinitive combinations:
d. Determiner + Noun
Tunnel bauen
'tunnel build'
combinations :
'a fly'

These types of two-word utterances represent different degrees of formal or conceptual complexity: Noun + Noun repetitions show no internal syntactic organization or semantic cohesion and are included as a control condition. They were very frequent initially and continued to be produced throughout the data collection period but do not undergo further syntactic or semantic integration (see also Veneziano et al., I 990: 647, for other children's early use of repetitions). In Noun + Particle and in Noun + Infinitive combinations, however, the infinitive and the particle open up a thematic role for the noun. These constructions are thus conceptually more complex than Noun + Noun repetitions, because the particle or verb predicates something over the noun. In addition, verbs are morphologically more complex than particles. Although we did not select the utterances by their semantic structure, there is a semantic similarity between these two types of utterances. Since subject omission is frequent in German child language, the noun tends to be the object or patient of the action rather than the agent (see Appendix I-4). In Determiner + Noun combinations, the determiner specifies the meaning of the noun, for example by making it definite or indefinite. From a syntactic viewpoint, Determiner + Noun combinations form a single Noun Phrase, whereas Noun + Particle and Noun + Infinitive combinations represent a hierarchical syntactic relationship since verbs and verbal particles govern the noun. 
TABLE I. Frequency of occurrence for the different types of two-word utterances

\begin{tabular}{cccccc}
\hline Age & $\begin{array}{c}\text { MLU } \\
\text { (words) }\end{array}$ & $\begin{array}{c}\text { Noun } \\
\text { + Noun }\end{array}$ & $\begin{array}{c}\text { Noun } \\
\text { +Particle }\end{array}$ & $\begin{array}{c}\text { Noun } \\
\text { +Infinitive }\end{array}$ & $\begin{array}{c}\text { Det } \\
+ \text { Noun }\end{array}$ \\
\hline $2 ; 0$ & $\mathrm{I} \cdot \mathrm{I}$ & $6 \cdot 7 \%$ & $0.5 \%$ & $0 . \mathrm{I} \%$ & $0.3 \%$ \\
$2 ; \mathrm{I}$ & $\mathrm{I} \cdot 3$ & $3 \cdot 0 \%$ & $\mathrm{I} \cdot \mathrm{I} \%$ & $0.6 \%$ & $0.5 \%$ \\
$2 ; 2$ & $\mathrm{I} \cdot 7$ & $\mathrm{I} \cdot 8 \%$ & $\mathrm{I} \cdot 2 \%$ & $\mathrm{I} \cdot 2 \%$ & $0.9 \%$ \\
$2 ; 3$ & $\mathrm{I} \cdot 8$ & $2 \cdot 3 \%$ & $\mathrm{I} \cdot 2 \%$ & $4 \cdot 0 \%$ & $9 \cdot \mathrm{I} \%$ \\
\hline
\end{tabular}

We analysed the first I 5 utterances of each type at $2 ; 0,2 ; 1,2 ; 2$, and $2 ; 3$. In this period, Leo's MLU in words (excluding repetitions) increases from I $\cdot$ I to $\mathbf{I} \cdot 8$ (all MLUs computed over the first ten days of each month, i.e. over $2 \cdot 646$ to $4 \cdot 296$ utterances). Only utterances transcribed as two-word utterances were analysed, and we discarded utterances distorted by excessive background noise or the voice of another speaker. However, we did not discard utterances based on pause-length. The longest pause found in the dataset was $\mathrm{I} \cdot 8$ seconds.

In most cases, more than one recording had to be analysed in order to find I 5 utterances of each type. We avoided conflating significant developmental changes within each investigation period by restricting the search space to a ten-day period and fewer than fifteen utterances if fewer were attested in a given ten-day period. That means that we only found six Noun+Infinitive and I 3 Determiner + Noun combinations at 2;0. Therefore, the total number of utterances we analysed is 229. Table I depicts the type frequency (in percent) of the four utterance types during the search periods for each age interval.

Table I shows that the three types of word combinations represent the 'cutting edge' of Leo's language development at 2; 0 when they each constitute less than I \% of all utterances in the search period. Noun + Particle combinations occur more frequently, whereas Noun + Infinitive constructions are just beginning to emerge. They are produced on a regular basis at 2; I. Precursors of Determiner + Noun constructions occur at 2;0, but the determiner - produced as a phonetically reduced form (e.g. schwa [ə]) - still has filler status. The vast majority of the 1950 nouns that Leo produced in the ten day period from 2; O. I to 2 ; 0 . I o occur without determiners or fillers. While Noun + Particle combinations stay on a relatively stable frequency level, Noun + Infinitive and Determiner + Noun combinations gradually increase in frequency over time. Together, they constitute I $5 \%$ of Leo's utterances at age $2 ; 3$.

All utterances are listed in Appendices $\mathrm{I}-4$ in orthographic transcription with an indication of intonation contours and pauses. Note that sometimes 
the same word combination is produced several times. These utterances can be repetitions in the same discourse context, but also new productions at a later point in time. The exact ages for all utterances analysed are provided in the Appendix, but for convenience, we will refer to the four data collection periods as age $2 ; 0,2 ; 1,2 ; 2$, and $2 ; 3$ in the remainder of this paper.

\section{Auditory analysis}

The prosody of all 229 child utterances was first analysed auditorily. The presence of a pause between lexical items, stressed syllables and the intonation contour on the stressed syllables were coded using the following symbols (see Appendices I-4):

(4) Symbols used in auditory analysis for pauses, stress and pitch movement

| pause

' stress and high level pitch

, stress and low level pitch

- $\quad$ stress and mid level pitch

$\backslash$ stress and falling pitch

/ stress and rising pitch

$\wedge \quad$ stress and rising-falling pitch

$\vee \quad$ stress and falling-rising pitch

\section{Instrumental analysis}

All utterances were analysed instrumentally using the speech software PRAAT. The following measurements were taken:

(5) a. length of pause between the two words

b. pitch height at the different points in the utterance (beginning and end of words, beginning and end of pitch movements, peaks)

Pauses of less than $60 \mathrm{~ms}$ before stops were not counted as pauses since they constitute the closure phase of the consonant. Pitch height was read from the fundamental frequency calculation provided automatically in PRAAT. Utterance-initial pitch height was measured at the beginning of the first vowel in the first word and utterance-final pitch height was measured at the end of the last vowel of the second word. In early child speech, microprosodic irregularities within the vowel such as caused by preceding voiced stops or nasals and subsequent vowels are very prominent (Gut, 2000). Also, the intrinsic pitch height of different vowel types varies greatly (e.g. Allen \& Hawkins, I978). Following standard phonetic procedure, such factors were taken into account in the measurements. In addition to these 


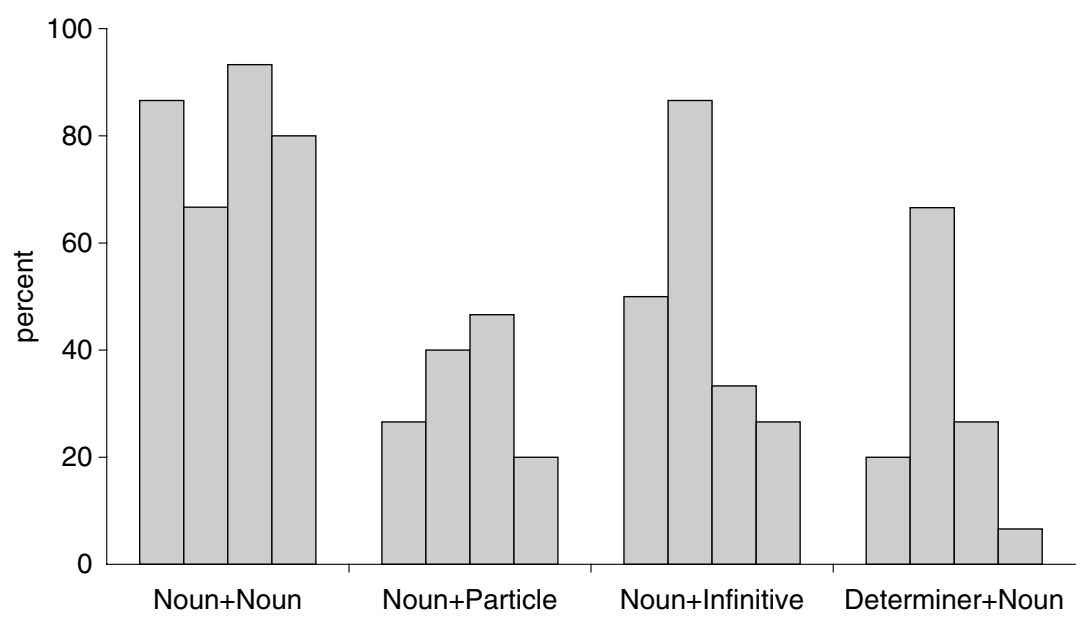

Fig. I. Percentage of utterances with a pause (per utterance type at $2 ; 0,2 ; 1$, $2 ; 2$, and $2 ; 3$ ).

measures, the variability of pause length and pitch height was analysed in order to investigate the stability of these features for each utterance type across development.

\section{RESULTS}

\section{Pauses}

Figure I illustrates the percentage of pauses in the four different types of two-word utterances. The four bars in each block represent the four measurement points. At 2;0, only two Determiner + Noun combinations have a pause. Of the thirteen two-word combinations of this type, eight have a filler-type determiner, which is not fully articulated, but reduced to either a schwa ([ə]), a single consonant [n] or a consonant + schwa syllable [də]] (see Appendix I). Pauses are also rare in Noun + Particle constructions (four of the fifteen), whereas half of the six Noun + Infinitive combinations and thirteen of fifteen Noun + Noun repetitions have a pause. At 2; , a sharp increase in the frequency of pauses can be observed in Determiner + Noun combinations (ten out of fifteen). This increase is associated with the changing nature of the determiner element: Now, only one of the fifteen determiners has a reduced phonetic form (see Appendix 2). At 2;2, the number of Determiner + Noun combinations with a pause decreases again, and at $2 ; 3$, only one of the fifteen utterances has a pause. The Noun + Infinitive combinations also have an increased frequency of pauses at 2; I (thirteen out of fifteen) compared to $2 ; 0$. From $2 ; 2$ on, 


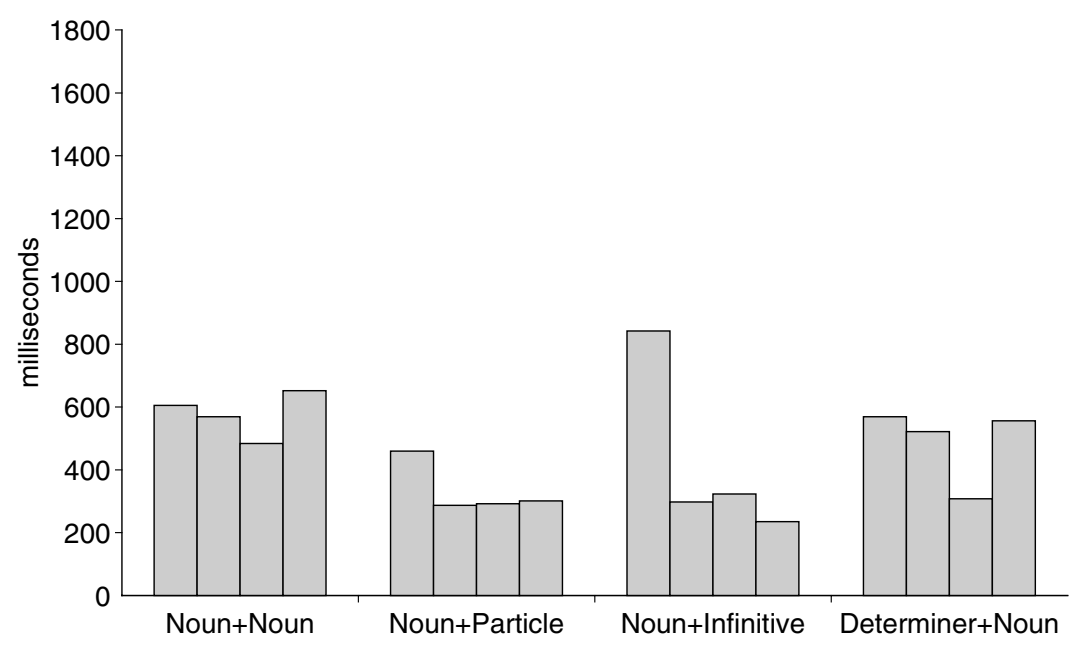

Fig. 2. Mean length of pause in milliseconds (per utterance type at 2;0, $2 ; 1,2 ; 2$, and $2 ; 3)$.

however, the proportion of utterances of this type with a pause drops again to one third (five out of fifteen). The peak of pause insertion in Noun + Particle combinations is reached at 2;2 (seven out of fifteen), after which it drops to a fifth of all productions. Noun + Noun repetitions constitute the type of two-word utterance that is most likely to be produced with a pause by Leo at all times.

There is some indication that at $2 ; 0$ and $2 ; \mathrm{I}$, the occurrence of a pause associates with the number of syllables in a word: A pause is more likely to occur when the first word of the two-word utterance is bisyllabic than in cases where the first word is monosyllabic ( $c f$. Appendices I and 2).

Figure 2 illustrates the mean length of the pauses found in the different types of two-word utterances across the four data points. For all types of word combinations, but not for the repetitions, the mean length of pauses decreases over time. Note that the increase in pause length for Determiner + Noun combinations at $2 ; 3$ is misleading: there is only one utterance with a fairly long pause, whereas the other I 4 examples have no pause at all. While there is no difference in the mean length of pauses between Noun + Particle and Noun + Infinitive combinations from 2; I onwards, at 2; 0 , Noun + Infinitive combinations have, on average, a considerably longer pause than Noun + Particle combinations. Noun + Noun repetitions are the only type of two-word utterances that do not show any decrease of mean pause length over time. Thus, Noun + Noun repetitions are not only most likely to have an intervening pause (see above) but also to have, on average, the longest pauses. 


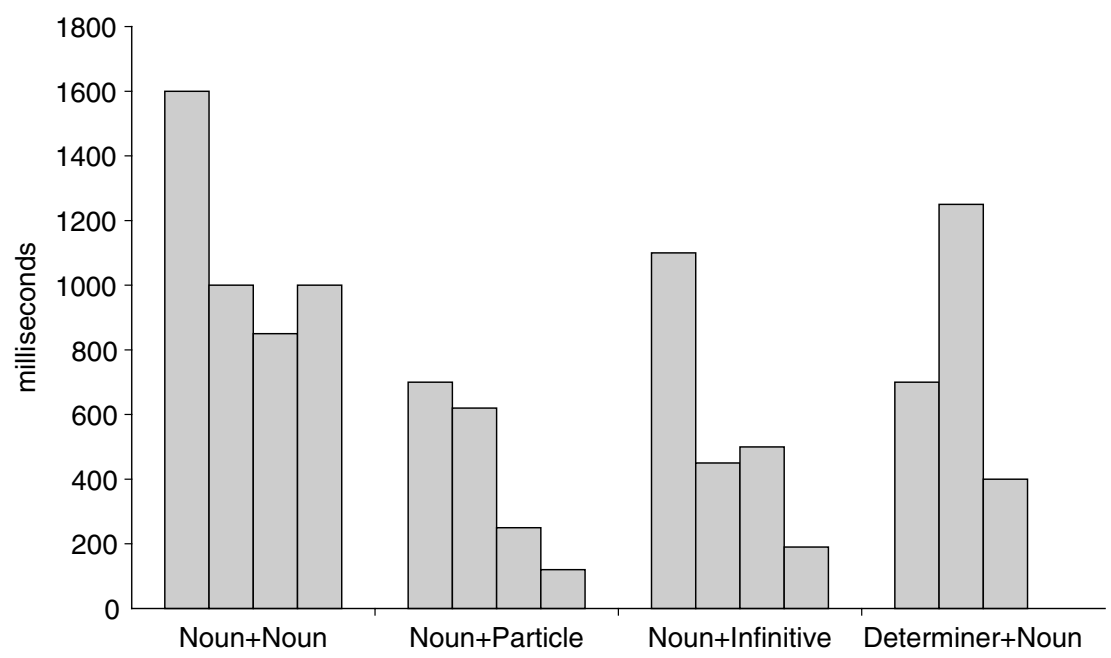

Fig. 3. Range of pause length in milliseconds (per utterance type at $2 ; 0$, $2 ; 1,2 ; 2$, and $2 ; 3)$.

\section{Variability of pause length}

In order to test the reliability of prosodic cues at the stage of first word combinations we calculated the range of pause length in the four types of two-word utterances produced by Leo between 2;0 and 2;3 (Figure 3). Noun + Noun repetitions and Noun + Infinitive combinations show the highest range of pause length at $2 ; 0$, Noun + Particle combinations at $2 ; 0$ and 2; 1 ; and Determiner + Noun combinations at 2; . The range of pause length decreases in the later months for all types of word combinations, but remains on a high level for the Noun + Noun repetitions.

\section{Stress pattern}

Table 2 illustrates the stress pattern with which Leo produced the four types of two-word utterances between 2 ; 0 and $2 ; 3$.

With only three exceptions at 2 ; , all Noun + Noun repetitions are produced with stress on both words. Noun + Particle combinations show an almost U-shaped development. They are produced with predominantly initial stress or stress on both words at $2 ; 0$ and again at 2;2. At 2; I, the stress pattern shifts to equal stress on both words. At 2;2, we again find an almost even mix between initial stress and stress on both words, while at $2 ; 3$ there is a predominance of initial stress.

The Noun + Infinitive combinations are first produced with two equally stressed words, but at $2 ; 2$ the stress shifts to predominantly initial stress. At $2 ; 3$, Leo's utterances of this type show all possible stress patterns: in six 
TAB BE 2. Token frequency of stress patterns attested in the four different types of two-word utterances

\begin{tabular}{|c|c|c|c|c|c|c|c|c|c|c|c|c|c|c|c|c|}
\hline \multirow[b]{2}{*}{ Age } & \multicolumn{4}{|c|}{ Noun-Noun } & \multicolumn{4}{|c|}{ Noun-Particle } & \multicolumn{4}{|c|}{ Noun-Infinitive } & \multicolumn{4}{|c|}{ Determiner-Noun } \\
\hline & $2 ; 0$ & $2 ; \mathrm{I}$ & $2 ; 2$ & $2 ; 3$ & $2 ; 0$ & $2 ; \mathrm{I}$ & $2 ; 2$ & $2 ; 3$ & $2 ; 0$ & $2 ; \mathrm{I}$ & $2 ; 2$ & $2 ; 3$ & $2 ; 0$ & $2 ; \mathrm{I}$ & $2 ; 2$ & $2 ; 3$ \\
\hline $\begin{array}{l}\text { First } \\
\text { word }\end{array}$ & & & & & 9 & I & 5 & I 2 & & & I I & 6 & & & 2 & \\
\hline $\begin{array}{c}\text { Second } \\
\text { word }\end{array}$ & & 3 & & & & & I & I & & & & 3 & 8 & 3 & 6 & Io \\
\hline $\begin{array}{l}\text { Both } \\
\text { words }\end{array}$ & I 5 & 12 & I 5 & I 5 & 6 & I4 & 9 & 2 & 6 & I 5 & 4 & 6 & 5 & 12 & 7 & 5 \\
\hline
\end{tabular}

cases both words are stressed, in three utterances it is the infinitive, and in the remaining six the noun.

Determiner + Noun combinations show an almost circular development in stress patterns that can be linked to the (phonetic) status of the determiner element. At 2; 0 , eight out of thirteen of the Determiner + Noun combinations carry stress only on the noun. A closer look at the utterances involved (Appendix I) shows that this is especially the case when the determiner is phonetically reduced and probably represents just a filler syllable. In contrast, four out of five utterances with a full determiner element have stress on both words. This tendency is even more pronounced at $2 ; \mathrm{I}$, when reduced determiners have almost disappeared and both determiner and noun have equal stress. All four bisyllabic and eight out of the eleven monosyllabic determiners are stressed at 2; I (see Appendix 2). A closer look at the context of stress determiners revealed that stress is most likely not contrastive in order to indicate quantitative differences. Only in some cases a second specimen of the named object was present (e.g. a pair of socks). However, in many cases a full determiner was produced by the adult interlocutors in the immediate context, for example in probing questions like was ist das, eine ...? 'what's that, a ....?' Leo sometimes - but not always - took up the determiner in his answer. The fact that many of the stressed determiners were present in the discourse context supports the interpretation that at $2 ; \mathrm{I}$, determiners are not fully productive.

A new stress pattern briefly appears at $2 ; 2$. In two of the Determiner + Noun combinations with the bisyllabic determiner eine (the feminine form of the indefinite determiner), the determiner carries the main stress of the utterance and the noun is unstressed (see Appendix 3). At 2; 3, however, all utterances are produced with stress on the noun again. As is the case at 2 ; 0 , five out of fifteen of the utterances now also have stress on the determiner.

The comparison of the four types of two-word utterances made evident that each of them has a distinct developmental pattern. However, at 2 ; 


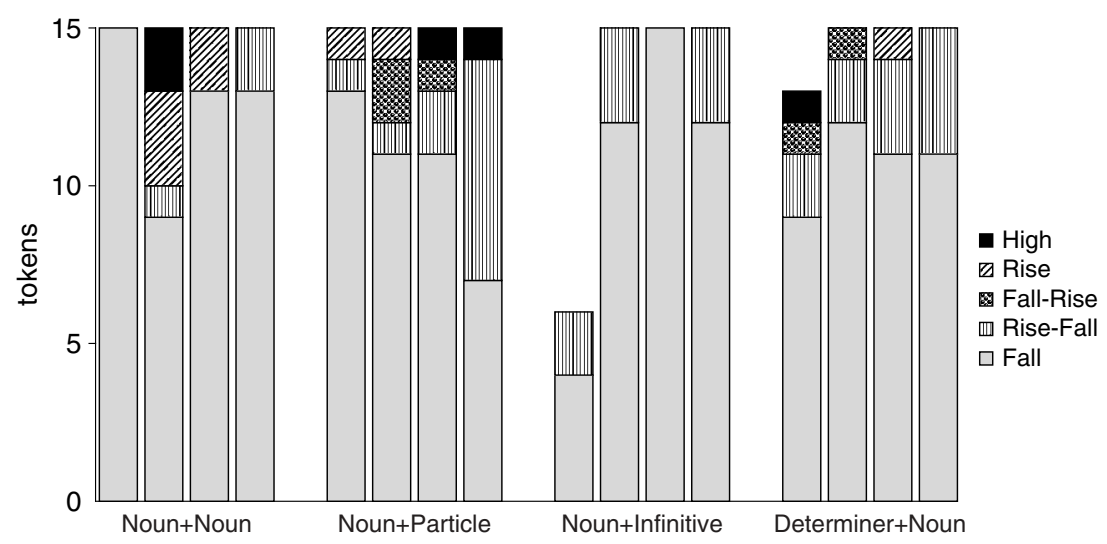

Fig. 4. Intonation contours (per utterance type at $2 ; 0,2 ; 1,2 ; 2$, and $2 ; 3$ ).

nearly all two-word utterances, irrespective of their type, are produced with stress on both words.

\section{Intonation}

Figure 4 shows the intonation contours of the four types of two-word utterances produced by Leo at each data point. It can be seen that across all types and times falling pitch movements are most frequent, followed by rise-falling pitch movements. Noun + Infinitive combinations show the most homogeneous intonation contours: they are always produced either with a falling or a rise-falling pitch movement. This may correlate with their phonetic homogeneity at the end of the utterance since all infinitives end in the unstressed syllable $-(e) n$. In contrast, nouns and particles can end in a multitude of different sounds and syllables.

In general, two-word utterances that end in high pitch (i.e. high level pitch, rises, and fall-rises) are very rare. At 2;0 Leo produced only one Noun + Particle and two Determiner + Noun combinations ending in high pitch. At 2; I, Leo's production of high-ending pitch movements has its peak with nine out of the total of 60 utterances. The high-ending pitch is found in five Noun + Noun repetitions, three Noun + Particle combinations and one Determiner + Noun combination. At 2;2 the total drops down to four again, and at 2;3 only one of the Determiner + Noun combinations ends in high pitch.

The greatest variety of pitch contours across all types of two-word utterances can be observed at 2; I. By 2;3, 43 of the 60 two-word utterances have a falling pitch contour and sixteen have a rise-fall contour. Thus, only one utterance does not end on a fall. 
TA ВLE 3. Mean pitch height (in $\mathrm{Hz}$ ) at the end of falls or rise-falls across all utterances

\begin{tabular}{lcccc}
\hline Age & $2 ; 0$ & $2 ;$ I & $2 ; 2$ & $2 ; 3$ \\
Mean pitch $(\mathrm{Hz})$ & 307,75 & 303 & 292,25 & 253,75 \\
\hline
\end{tabular}

TABLE 4. Mean pitch in MhZ (S.D.) at the end of falls

\begin{tabular}{ccccr}
\hline Age & Noun + Noun & Noun + Particle & Noun + Infinitive & Det + Noun \\
\hline $2 ; 0$ & $3 \mathrm{I} 4,2(46,5)$ & $326,4(32,6)$ & $323,8(42,6)$ & $320,8(46,8)$ \\
$2 ; \mathrm{I}$ & $359,3(46,8)$ & $339,6(58,7)$ & $33 \mathrm{I}, \mathrm{I}(4 \mathrm{I}, 3)$ & $260,4(25,6)$ \\
$2 ; 2$ & $297,9(43,5)$ & $27 \mathrm{I}, 8(33,4)$ & $268,4(20,8)$ & $28 \mathrm{I}(56,2)$ \\
$2 ; 3$ & $254,2(44,9)$ & $276,4(36,5)$ & $26 \mathrm{I}, \mathrm{I}(36,8)$ & $238(22,4)$ \\
\hline
\end{tabular}

Table 3 lists the mean pitch height in $\mathrm{Hz}$ at the end of falling or risefalling pitch movements across all types of two-word utterances at each data point.

The pitch height at the lowest end point of the falls and rise-falls decreases steadily from $307.75 \mathrm{~Hz}$ at 2 ; o to $253.75 \mathrm{~Hz}$ at 2 ; 3 . In order to check whether this decrease in pitch height is simply due to physiological development (i.e. the lengthening of Leo's vocal cords), we compared the development of pitch height at the beginning and the end of falling intonation contours.

\section{Variability of intonation at the beginning and the end of falling contours}

In the final analysis, we investigate the pitch height (in $\mathrm{MHz}$ ) and the variability of pitch height of all falling pitch movements produced by Leo. The variability of pitch height is calculated as the standard deviation both at the end and at the beginning of each falling pitch contour. Table 4 shows the development of pitch height and its variability at the end of all falling pitch movements (we only included falling pitch movement that ended low, not mid). While the absolute pitch height at the end of falling intonation contours is lower at $2 ; 3$ than at $2 ; 0$, there is no decrease in the variability. The pitch height at the beginning of falling pitch movements (Table 5) does not decrease for all utterance types, but only for the Noun + Infinitive and Determiner + Noun combinations.

Because there are no comparative data from other children or adults, the measures of pitch height and their standard deviation are difficult to interpret. The fact that the pitch height at the beginning of falls does not generally become lower might indicate that the lowering at the end of falls is not purely due to physiological development. 
TABLE 5. Mean pitch in MhZ (s.D.) at the beginning of falls

\begin{tabular}{ccccc}
\hline Age & Noun + Noun & Noun + Particle & Noun + Infinitive & Det + Noun \\
\hline $2 ; 0$ & $392,3(4 \mathrm{I}, 9)$ & $383,6(42,9)$ & $42 \mathrm{I}, 8(44,7)$ & $369,8(46,7)$ \\
$2 ; \mathrm{I}$ & $427,0(5 \mathrm{I}, 7)$ & $39 \mathrm{I}, 6(49,3)$ & $404,5(35,3)$ & $308,3(29,6)$ \\
$2 ; 2$ & $407,5(57,5)$ & $402,3(55,2)$ & $406,9(42,5)$ & $342,3(66, \mathrm{I})$ \\
$2 ; 3$ & $397,7(4 \mathrm{I}, 3)$ & $378,9(64,2)$ & $362,7(33,4)$ & $289,5(3 \mathrm{I}, 5)$ \\
\hline
\end{tabular}

\section{DISCUSSION AND CONCLUSION}

This study investigated the prosodic properties of early combinatorial speech in one child acquiring German. We analysed four different types of two-word utterances across the first three month after the onset of multiword speech at 2 ; 0 .

The first aim of the paper was to find relationships between different syntactic types of two-word utterances and various prosodic cues. The data show that different types of two-word utterances undergo different developmental trajectories. An acoustic analysis of these utterances revealed that Noun + Noun repetitions have different prosodic properties from the other types of two-word combinations. They are most likely to be produced with an intervening pause and have the longest pause of all investigated utterances. In addition, in Noun + Noun repetitions both words are almost always stressed and produced with a falling pitch contour. Only at 2; , other stress patterns occur and other intonation patterns than falls are produced. In sum, Noun + Noun repetitions do not show signs of increasing prosodic integration in this developmental period. The high range in pause length and the variability in utterance-final pitch at the end of the observation period support this interpretation.

Noun + Particle combinations are the type of utterance with the fewest and the shortest pauses throughout. However, they show a reorganization in stress patterns and intonation contour: at 2 ; $\mathrm{I}$, both words are stressed while initial stress predominates at 2;0 and from 2;2 onwards. Simultaneously, the variety of different pitch movements produced with this type of twoword combination is highest at $2 ; \mathrm{I}$.

Up to $2 ; 2$, Noun + Infinitive combinations are likely to be produced with a pause. Similarly, up to $2 ; 2$ all utterances of this type have equal stress on both words. At 2;2, a majority of the Noun + Infinitive combinations are stressed only on the noun. In contrast, they have an unclear stress pattern at $2 ; 3$. In terms of intonation, these utterances are never produced with pitch movements ending high.

Determiner + Noun combination are most likely to be separated by a pause at $2 ; \mathrm{I}$. The earliest Determiner + Noun combinations at 2;0 are predominately stressed only on the noun, but they often show a phonetically 
reduced determiner. It is noticeable that when the determiner is produced in full phonetic form at around $2 ; \mathrm{I}$, it is stressed, sometimes even as the only stressed word in the two-word utterance. That is, this stress pattern deviates from the adult pattern, where the determiner is usually unstressed, unless it is emphasized. At 2;3, Leo produced the unmarked adult pattern 'unstressed determiner plus stressed noun' without intervening pause. The intonation contour of such utterances is mostly falling. This course of development suggests a reorganization from initially unanalysed filler plus noun structures with holistic intonation contour (level stress) to the final metrical and prosodic integration of determiner and noun ( $c f$. Peters, I 995 for similar developmental trajectories).

The second aim of the paper was to measure the development of selected prosodic aspects of speech. The following general trends can be observed: the frequency of pauses in all word combinations excluding the Noun + Noun repetitions, shows a clear decrease from 2; o to 2; 3. Likewise, the length of intervening pauses and the variability in their duration decreases in the observation period. These observations tie in with findings for another child acquiring German, studied by Kaltenbacher (r 990). At an MLU of ${ }_{1} \cdot 0_{4}$, she produced all Noun + Infinitive and Noun + Particle twoword combinations with an intervening pause. Five months later, the number had fallen to $52 \%$. Also, the average absolute length of the pauses had decreased from $720 \mathrm{~ms}$ to 4 I I ms. Two-word utterances comprising two (different) nouns showed a similar pattern.

Comparing the stress patterns of all two-word utterances over time reveals a phase at 2 ; $\mathrm{I}$ in which nearly all utterances have equal stress on both words. Even those utterances, which had a distinct stress pattern at 2; 0 (Noun + Particle combinations have initial stress and Determiner + Noun combinations have final stress) show this equal-stress pattern at 2; I before 'returning' to their original patterns. This suggests a fundamental restructuring of Leo's stress production at this stage. Possibly it reflects a restructuring of the underlying metrical form from a single foot to two feet with quantity sensitivity, as described for the development of word stress by Fikkert (1994) and Fikkert et al. (1998). This hypothesis will have to be substantiated in future research by a full-fledged analysis where the stress patterns of multi-syllabic words are compared to those in word combinations. Likewise, the restructuring phase might reflect the emergence of the prosodic domain of phrasal stress. In the transition from single-word to multiword utterances, children have to work out the details of the interaction of word stress and phrasal stress in such a way that word stress becomes optional as in adult speech, where its realization depends on speech rate and pragmatic intentions. Future research is required to determine the emergence of phrasal stress and its relationship to word stress. For example, at $2 ; 0$ and $2 ; \mathrm{I}$, a bisyllabic word tends to co-occur with a pause and / or 
onset stress of the second word. It is possible that in language production, strong trochaic word stress initially inhibits the prosodic integration of two words into a single prosodic phrase. However, this could also indicate a lack of semantic integration in a way that both words initially carry equal semantic weight (see above). In this regard, the acquisition of (contrastive) stress to mark focus distinctions is of crucial interest. Recall that Bloom (I 973) noted that in the transition from single word to multiword utterances focus did not appear to be linguistically encoded by word order or stress. However, Purnell (r 997) found that children in the two-word stage used stress as well as word order to highlight topics as opposed to comments, whereas children in the three-word stage used stress rather than word order.

The prosodic restructuring at 2 ; $\mathrm{I}$ is also associated with peculiarities in Leo's intonation. Across all utterance types there is a wider range of pitch movements than at $2 ; 0$ or from $2 ; 2$ on. The preponderant intonation contour across all types of utterances and all data points is a falling or rise-falling one.

Leo's prosodic development is also reflected in the variability of prosodic features such as pause length and pitch contours. Pitch height at the beginning of falls varies across all types of two-word utterances across development, and no clear developmental trends can be identified. In contrast, the pitch height at the end of falls decreases in absolute terms $(\mathrm{MHz})$ for all types of utterances. This might indicate that lower pitch movements are not just due to physiological development. Since we do not have data from other children or adults that could serve for comparison, we have to rely on future research to investigate whether pitch height can be related to syntactic development.

The third aim of this paper was to provide an assessment of the reliability of prosodic cues for syntactic development in early child speech. The Noun + Noun repetitions that served as a control condition show no development across the three-month period: both words are stressed, they are often interrupted by pauses, and at later stages they show the highest variability regarding pause length and utterance-final pitch height. With these features, they correspond to the prosodic characteristics of SUCCESsIvE SINGLE WORD UTTERANCES (SSWUs) discussed above and do not show development towards increasing prosodic integration. In contrast, the three types of word combinations end up showing the characteristics of prosodic integration outlined above. For example, all two-word combinations now tend to be produced without pauses.

The main result of our study is that the prosodic properties found at $2 ; 3$ develop along different paths. The three different types of word combination become prosodically integrated at different points in time, and represent heterogeneous sets at earlier measurement points. The high variability of pause length and pitch contours at 2; 0 and 2 ; I suggests that 
these prosodic cues should not be taken as evidence for semantic cohesion or non-cohesion at such an early stage. This becomes obvious when looking at the minimal pairs found in our dataset ( $c f$. Appendix $\mathrm{I}-4)$. Here, the same combinations of lexical items show different prosodic realizations, which demonstrate the variability of prosodic features. For example, one twoword utterance produced with an intervening pause would, a little later, be produced without an intervening pause. In agreement with Branigan (I 979), we conclude that the distinction of SSWUs and multiword utterances on prosodic grounds such as length of pause or intonation contour is difficult to make.

In sum, we call for caution when taking prosody as a diagnostic cue for syntactic development in the earliest stages of language development. Recall that the prosodic features were the most variable at 2 ; 1 , when Leo had already produced two-word utterances on a regular basis for more than a month. Furthermore, in some areas we see cyclic development in the sense that at $2 ; 3$, Leo ends up where he started out at 2;0. This holds for the stress patterns observed in Noun + Particle and Determiner + Noun combinations. Such cyclic development indicates a developmental trajectory from unanalysed holistic strings to analysed combinations. Again, the long transitional and reorganizational phases found for some types of multiwordconstructions suggest that prosody is an unreliable independent cue for the degree of syntactic organization of individual utterances at these early stages.

With this study we hope to have opened the window towards a more systematic investigation of the prosody of children's early multiword speech. We are well aware that this is only a beginning and that our study raises a number of additional questions. For example: can we find more stable prosodic patterns or templates when we look at utterances which are even more similar to one another (e.g. treat different determiners separately, or control for the number of syllables of the words)? Our data suggest that the absolute number of syllables in a two-word utterance is associated with the presence of pauses. In the data from 2; 0 and $2 ; \mathrm{I}$, in cases where the first word consists of more than one syllable, the second words is frequently separated by a pause or receives stress. A more systematic analysis of this aspect needs to follow.

Although some prosodic features tend to become more stable as development proceeds, we need to add a caveat: prosody is variable even in adult speech. It would therefore be unreasonable to expect fixed values and completely stable prosodic properties. As of yet, the issue of 'benchmarking' prosodic features is an open one.

Nonetheless, our results raise a number of further issues. Is the fluency of early multiword utterances related to their frequency in such a way that more frequent combinations are more fluent than new and unrehearsed 
ones? When does prosody start to indicate different speech acts by rises or falls at the end of the utterance? When and how does phrasal stress emerge, and is it related to the development of word stress? For methodological reasons we restricted ourselves to two-word utterances although Leo already produces longer ones. Future research will also have to show how the prosody of short multiword utterances relates to the prosodic structure of longer ones.

\section{REFERENCES}

Allen, G. \& Hawkins, S. (1978). The development of phonological rhythm. In A. Bell \& J. Hooper (eds), Syllables and segments. Amsterdam: North Holland Publishing Company.

Archibald, J. (I 995). The acquisition of stress. In J. Archibald (ed.), Phonological acquisition and phonological theory. Hillsdale, $\mathrm{NJ}$ : Erlbaum.

Bassano, D. \& Mendes Maillochon, I. (I 994). Early grammatical and prosodic marking of utterance modality in French: a longitudinal case study. Fournal of Child Language 2r, $649-75$.

Bates, E. \& Goodman, J. (I999). On the emergence of grammar from the lexicon. In B. MacWhinney (ed.), The emergence of language. Mahwah, NJ : Erlbaum.

Bloom, L. (1970). Language development: form and function in emerging grammars. Cambridge, MA: MIT Press.

Bloom, L. (1973). One word at a time. The Hague: Mouton.

Braine, M. D. S. ( 1963$)$. The ontology of English phrase structure: the first phase. Language 39, I-I3.

Braine, M. D. S. (1976). Children's first word combinations. Monographs of the Society for Research in Child Development ( $I$, Serial No. I64) 4r.

Branigan, G. (1979). Some reasons why successive single word utterances are not. Fournal of Child Language 6, $4 \mathrm{I}$ I-2 I.

Crystal, D. (I 986). Prosodic development. In P. Fletcher \& M. Garman (eds), Language acquisition: studies in first language development. Second edition. Cambridge: CUP.

D'Odorico, L. \& Carubbi, S. (2003). Prosodic characteristics of early multi-word utterances in Italian children. First Language $\mathbf{2 3}, 97-\mathrm{I} \mathbf{1} 6$.

Dore, J. (1 975). Holophrases, speech acts and language universals. Fournal of Child Language 2, 2 I-40.

Fenson, L., Dale, P. S., Reznick, J. S., Thal, D., Bates, E., Hartung, J. P., Pethick, S. \& Reilly, J. S. (1993). The MacArthur communicative development inventories : user's guide and technical manual. San Diego: Singular Publishing Group.

Fikkert, P. (1 994). On the Acquisition of Prosodic Structure. Dordrecht: ICG Printing (HIL Dissertations).

Fikkert, P., Penner, Z. \& Wymann, K. (1998). Das Comeback der Prosodie. Neue Wege in der Diagnose und Therapie von phonologischen Störungen. Logos interdisziplinär 6, 84-97.

Flax, J., Lahey, M., Harris, K. \& Boothroyd, A. (I99I). Relations between prosodic variables and communicative function. Fournal of Child Language $\mathbf{1 8}, 3^{-1} 9$.

Furrow, D. (1984). Young children's use of prosody. Fournal of Child Language II, 203-1 3.

Galligan, R. (1987). Intonation with single words: purposive and grammatical use. Fournal of Child Language 14, I-2 I.

Gut, U. (2000). The acquisition of intonation by German/English bilingual children. Tübingen: Niemeyer.

Halliday, M. (1975). Learning how to mean. London: Edward Arnold.

Kaltenbacher, E. (I 990). Strategien beim frühkindlichen Syntaxerwerb. Tübingen: Narr.

Kehoe, M., Stoel-Gammon, C. \& Buder, E. (1995). Acoustic correlates of stress in young children's speech. Fournal of Speech and Hearing Research 38, 338-50. 
Kubaska, C. \& Keating, P. (I98I). Word duration in early child speech. Fournal of Speech and Hearing Research 24, 6I 5-2 I.

Laufer, M. (I980). Temporal regularity in prespeech. In T. Murry \& A. Murry (eds), Infant communication: cry and early speech. San Diego: College Hill Press.

Marcos, H. (1987). Communicative functions of pitch range and pitch direction in infants. Fournal of Child Language 14, 255-68.

MacWhinney, B. (2000). The CHILDES-project: tools for analyzing talk. Third edition. Hillsdale, NJ : Erlbaum.

Peters, A. (1995). Strategies in the acquisition of syntax. In P. Fletcher \& B. MacWhinney (eds), Handbook of language acquisition. Oxford: Blackwell.

Pollock, K., Brammer, D. \& Hageman, C. (1993). An acoustic analysis of young children's production of word stress. Fournal of Phonetics 21, I 83-203.

Purnell, E. (1997). The missing link: prosodic marking in the two-word stage. Paper presented at the GALA conference, Edinburgh.

Robb, M. \& Saxman, J. ( 1989 ). Syllable durations of preword and early word vocalizations. Fournal of Speech and Hearing Research 33, 583-93.

Rodgon, M. (1976). Single-word usage, cognitive development and the beginnings of combinatorial speech. Cambridge: CUP.

Scollon, R. (I 979). A real early stage: an unzippered condensation of a dissertation on child language. In E. Ochs \& B. Schieffelin (eds), Developmental pragmatics. New York: Academic Press.

Snow, D. (1994). Phrase-final syllable lengthening and intonation in early child speech. Fournal of Speech and Hearing Research 37, 831-40.

Tracy, R. (I99I). Sprachliche Strukturentwicklung: Linguistische und kognitionspsychologische Aspekte einer Theorie des Erstspracherwerbs. Tübingen: Narr.

Veneziano, E. \& Sinclair, H. (2000). The changing status of 'filler syllables' on the way to grammatical morphemes. Fournal of Child Language 27, 46 I-500.

Veneziano, E., Sinclair, H. \& Berthoud, I. (1990). From one word to two words: repetition patterns on the way to grammatical morphology. Fournal of Child Language 17, 6 I-82.

Wijnen, F. (1990). The development of sentence planning. Fournal of Child Language 17, $65 \mathrm{I}-75$.

\section{APPENDIX I}

LEO'S TWO-WORD UTTERANCES AT 2;O

Transcription of intonation:

falling pitch movement

/ rising pitch movement

' high level pitch

, low level pitch

- mid level pitch

| pause 
(a) Noun + Noun repetitions

\begin{tabular}{|c|c|c|c|c|}
\hline$\#$ & Age & $\begin{array}{l}\text { Utterance } \\
\text { intonation }\end{array}$ & $\begin{array}{c}\text { Utterance } \\
\text { orthographic }\end{array}$ & Gloss \\
\hline I & $2 ; 0.1$ & $\backslash$ Schornstein $\mid \backslash$ Schornstein & Schornstein & chimney \\
\hline 2 & $2 ; 0.1$ & $\backslash$ Kuckak | \Kuckak & Geburtstag & birthday \\
\hline 3 & $2 ; O . I$ & $\backslash$ Euter $\backslash$ Euter & Euter & udder \\
\hline 4 & $2 ; 0.1$ & $\backslash$ Sanje | \Sanje & Orange & orange \\
\hline 5 & $2 ; O . I$ & $\backslash$ Eichi $\mid \backslash$ Eichi & Eichi & squirrel \\
\hline 6 & $2 ; 0.1$ & $\backslash$ Eichi $\mid \backslash$ Eichi & Eichi & squirrel \\
\hline 7 & $2 ; 0.1$ & $\mid$ Tür $\mid \backslash$ Tür & Tür & door \\
\hline 8 & $2 ; 0.1$ & $\backslash$ Bauer | \Bauer & Bauer & farmer \\
\hline 9 & $2 ; 0.1$ & $\backslash$ Tür $\backslash$ Tür & Tür & door \\
\hline IO & $2 ; 0.1$ & $\backslash$ Eichi $\mid \backslash$ Eichi & Eichi & squirrel \\
\hline I I & $2 ; 0.1$ & $\backslash$ Bauer | \Bauer & Bauer & farmer \\
\hline I 2 & $2 ; O . I$ & $\backslash$ Schornstein $\mid \backslash$ Schornstein & Schornstein & chimney \\
\hline I 3 & $2 ; 0.1$ & $\backslash$ Hunger $\mid \backslash$ Hunger & Hunger & hunger \\
\hline I 4 & $2 ; O . I$ & $\backslash$ Hunger $\mid \backslash$ Hunger & Hunger & hunger \\
\hline I 5 & $2 ; 0.1$ & $\backslash$ Häuschen | \Häuschen & Häuschen & house-DIM \\
\hline
\end{tabular}

(b) Noun + Particle combinations

\begin{tabular}{|c|c|c|c|c|}
\hline$\#$ & Age & $\begin{array}{l}\text { Utterance } \\
\text { intonation }\end{array}$ & $\begin{array}{c}\text { Utterance } \\
\text { orthographic }\end{array}$ & Gloss \\
\hline I & $2 ; O . I$ & $\backslash$ Tür zu & Tür zu & door closed \\
\hline 2 & $2 ; O . I$ & $\backslash$ Tür zu & Tür zu & door closed \\
\hline 3 & $2 ; 0.1$ & $\backslash$ Tür zu & Tür zu & door closed \\
\hline 4 & $2 ; 0.1$ & 'Tür \zu: & Tür zu & door closed \\
\hline 5 & $2 ; O . I$ & $\backslash$ Tür zu & Tür zu & door closed \\
\hline 6 & $2 ; 0.3$ & $\backslash$ Block | \drauf & Block drauf & brick on \\
\hline 7 & $2 ; 0.3$ & 'Kerze | ,an & Kerze an & candle on \\
\hline 8 & $2 ; 0.3$ & /Rauch \aus & Rauch raus & smoke out \\
\hline 9 & $2 ; 0.3$ & $\backslash$ Rauch raus & Rauch raus & smoke out \\
\hline IO & $2 ; 0.5$ & $\backslash$ Rauch raus & Rauch raus & smoke out \\
\hline I I & $2 ; 0.5$ & $\backslash$ Bobo $\mid \backslash$ hoch & Bobo hoch & Bobo (=name) up \\
\hline 12 & $2 ; 0.6$ & $\backslash$ Rauch raus & Rauch raus & smoke out \\
\hline I 3 & $2 ; 0.6$ & $\backslash$ Rauch raus & Rauch raus & smoke out \\
\hline I 4 & $2 ; 0.7$ & /Hund | /los & Hund los & dog loose \\
\hline I 5 & $2 ; 0.7$ & $\backslash$ Rauch raus & Rauch raus & smoke out \\
\hline
\end{tabular}


(c) Noun + Infinitive combinations

\begin{tabular}{|c|c|c|c|c|}
\hline \# & Age & $\begin{array}{l}\text { Utterance } \\
\text { intonation }\end{array}$ & $\begin{array}{c}\text { Utterance } \\
\text { orthographic }\end{array}$ & Gloss \\
\hline I & $2 ; 0.1$ & /Bag | \schliessen & Bagger schliessen & digger close \\
\hline 2 & $2 ; 0.6$ & $\backslash$ afn, $\mathrm{n}$ & Apfelsaft trinken & applejuice drink \\
\hline 3 & $2 ; 0.7$ & 'Buch -holen & Buch holen & book fetch \\
\hline 4 & $2 ; 0.8$ & /Fisch | \angeln & Fisch angeln & fish fish \\
\hline 5 & $2 ; 0.8$ & $\backslash$ Kirschen $\mid \backslash$ haben & Kirschen haben & cherries have \\
\hline 6 & $2 ; 0.9$ & $\backslash$ Eichi $\backslash$ holen & Eichi holen & squirrel fetch \\
\hline
\end{tabular}

(d) Determiner + Noun combinations

\begin{tabular}{rllll}
\hline$\#$ & Age & \multicolumn{1}{c}{$\begin{array}{c}\text { Utterance } \\
\text { phonetic }\end{array}$} & $\begin{array}{c}\text { Utterance } \\
\text { orthographic }\end{array}$ & Gloss \\
\hline I & $2 ; 0.3$ & e $\backslash$ Schornstein & ein Schornstein & a chimney \\
2 & $2 ; 0.3$ & e $\backslash$ Schornstein & $\begin{array}{l}\text { ein Schornstein } \\
\text { ein(e) Eule }\end{array}$ & $\begin{array}{l}\text { a chimney } \\
\text { an owl }\end{array}$ \\
3 & $2 ; 0.5$ & $\backslash$ ein $\backslash$ Eule & ein Kuchen & a cake \\
4 & $2 ; 0.5$ & ein $\backslash$ Kuchen & ein Dreirad & a tricycle \\
5 & $2 ; 0.5$ & e $\backslash$ Dreirad & die Autos & the cars \\
6 & $2 ; 0.6$ & de $\backslash$ Autos & ein Mann & a man \\
7 & $2 ; 0.7$ & ein $/$ Mann & ein Laster & a truck \\
8 & $2 ; 0.7$ & e $\backslash \backslash$ Laster & ein Mantel & a coat \\
9 & $2 ; 0.8$ & ein $\backslash$ Mantel $\backslash$ Stein & ein Stein & a stone \\
I0 & $2 ; 0.8$ & eine Torte & a tart \\
I I & $2 ; 0.9$ & $\backslash$ eine $\backslash$ Torte & ein Tisch & a table \\
I 2 & $2 ; 0.9$ & n 'Tisch & ein Kopf & a head \\
I3 & $2 ; 0.9$ & e $\backslash$ Kopf & & \\
\hline
\end{tabular}




\section{APPENDIX 2}

LEO'S TWO-WORD UTTERANCES AT 2; I

(a) Noun + Noun repetitions

\begin{tabular}{|c|c|c|c|c|}
\hline \# & Age & $\begin{array}{l}\text { Utterance } \\
\text { intonation }\end{array}$ & $\begin{array}{c}\text { Utterance } \\
\text { Orthographic }\end{array}$ & Gloss \\
\hline I & $2 ; \mathrm{I} \cdot 3$ & Arm 'Arm & Arm & arm \\
\hline 2 & $2 ; 1 \cdot 3$ & Arm $\backslash$ Arm & Arm & arm \\
\hline 3 & $2 ; 1 \cdot 3$ & $\backslash$ Auto $\backslash$ Auto & Auto & car \\
\hline 4 & $2 ; \mathrm{I} \cdot 3$ & $\backslash$ Bagger | \Bagger & Bagger & digger \\
\hline 5 & $2 ; 1 \cdot 3$ & Bau \klötzer | Bau \klötzer & Bauklötze & building blocks \\
\hline 6 & $2 ; 1 \cdot 3$ & /Buch | /Buch & Buch & book \\
\hline 7 & $2 ; 1 \cdot 3$ & $\backslash$ Eichi $\mid \backslash$ Eichi & Eichi & squirrel \\
\hline 8 & $2 ; \mathrm{I} \cdot 3$ & /Eich $\mid \wedge$ Eichi & Eichi & squirrel \\
\hline 9 & $2 ; 1 \cdot 3$ & /Fisch $\mid /$ Fisch & Fisch & fish \\
\hline IO & $2 ; \mathrm{I} \cdot 3$ & Fisch | 'Fisch & Fisch & fish \\
\hline I I & $2 ; 1 \cdot 3$ & $\backslash$ Gras $\mid \backslash$ Gras & Gras & grass \\
\hline I 2 & $2 ; \mathrm{I} \cdot 3$ & $\backslash \mathrm{Oma} \mid \backslash \mathrm{Oma}$ & Oma & granny \\
\hline I 3 & $2 ; \mathrm{I} .4$ & $\backslash$ Bobo $\backslash$ Bobo & Bobo & Bobo (proper name) \\
\hline I 4 & $2 ; \mathrm{I} .4$ & /Bobo 'Bobo & Bobo & Bobo \\
\hline I 5 & $2 ; 1.4$ & 'Wusch | -Wusch & Wurst & sausage \\
\hline
\end{tabular}

(b) Noun + Particle combinations

\begin{tabular}{|c|c|c|c|c|}
\hline$\#$ & Age & $\begin{array}{l}\text { Utterance } \\
\text { intonation }\end{array}$ & $\begin{array}{c}\text { Utterance } \\
\text { orthographic }\end{array}$ & Gloss \\
\hline I & $2 ; \mathrm{I} \cdot 3$ & 'Mama ,mit & Mama mit & Mummy with \\
\hline 2 & $2 ; 1.3$ & -Buch \vor & Buch vor & book $\operatorname{vor}(\operatorname{vorlesen}=$ read $)$ \\
\hline 3 & $2 ; \mathrm{I} \cdot 3$ & 'Buch \vor & Buch vor & book $\operatorname{vor}(\operatorname{vorlesen}=$ read $)$ \\
\hline 4 & $2 ; \mathrm{I} \cdot 3$ & $\backslash$ Buch vor & Buch vor & book $\operatorname{vor}(\operatorname{vorlesen}=$ read $)$ \\
\hline 5 & $2 ; \mathrm{I} \cdot 3$ & 'Buch -vor & Buch vor & book $\operatorname{vor}(\operatorname{vorlesen}=$ read $)$ \\
\hline 6 & $2 ; \mathrm{I} \cdot 3$ & 'Buch | |vor & Buch vor & book $\operatorname{vor}(\operatorname{vorlesen}=$ read $)$ \\
\hline 7 & $2 ; \mathrm{I} \cdot 3$ & 'Buch \vor & Buch vor & book $\operatorname{vor}(\operatorname{vorlesen}=$ read $)$ \\
\hline 8 & $2 ; \mathrm{I} \cdot 3$ & 'Buch \vor & Buch vor & book $\operatorname{vor}(\operatorname{vorlesen}=$ read $)$ \\
\hline 9 & $2 ; \mathrm{I} \cdot 3$ & /Nuss | -auf & Nuss auf & nut open \\
\hline IO & $2 ; \mathrm{I} \cdot 3$ & $\backslash$ Tunnel | /raus & Tunnel raus & tunnel out \\
\hline I I & $2 ; \mathrm{I} .4$ & 'Rauch \raus & Rauch raus & smoke out \\
\hline 12 & $2 ; \mathrm{I} .4$ & 'Rauch \raus & Rauch raus & smoke out \\
\hline I 3 & $2 ; \mathrm{I} \cdot 5$ & 'Auge | \zu & Auge zu & eye shut \\
\hline I 4 & $2 ; \mathrm{I} \cdot 5$ & /Lok | 'hoch & Lok hoch & locomotive up \\
\hline I 5 & $2 ; \mathrm{I} \cdot 5$ & \Hänger | 'weg & Hänger weg & carriage off \\
\hline
\end{tabular}


(c) Noun + Infinitive combinations

\begin{tabular}{|c|c|c|c|c|}
\hline$\#$ & Age & $\begin{array}{l}\text { Utterance } \\
\text { intonation }\end{array}$ & $\begin{array}{c}\text { Utterance } \\
\text { orthographic }\end{array}$ & Gloss \\
\hline I & $2 ; 1 \cdot 3$ & 'Autos -holen & Autos holen & cars fetch \\
\hline 2 & $2 ; 1.3$ & 'Tunnel | ,bauen & Tunnel bauen & tunnel build \\
\hline 3 & $2 ; 1 \cdot 3$ & $\backslash$ Glocke | ^laeuten & Glocke läuten & bell ring \\
\hline 4 & $2 ; 1.4$ & 'Bus | $\wedge$ fahren & Bus fahren & bus ride \\
\hline 5 & $2 ; \mathrm{I} .4$ & $\backslash$ Erdbeer $\mid \backslash$ haben & Erdbeere haben & strawberry have \\
\hline 6 & $2 ; 1.5$ & /Gans | \trinken & Gans trinken & goose drink \\
\hline 7 & $2 ; 1 \cdot 5$ & $\backslash$ Fische $\mid$,spielen & Fische spielen & fish play \\
\hline 8 & $2 ; 1 \cdot 5$ & $\backslash$ Kuh | \baden & Kuh baden & cow bathe \\
\hline 9 & $2 ;$ 1.6 & $\backslash$ Bua | \gucken & Buch gucken & book look \\
\hline IO & $2 ; 1.6$ & 'Tisch | -fahren & Tisch fahren & table ride \\
\hline I I & $2 ; 1.6$ & $\backslash$ Essen $\mid \backslash$ holen & Essen holen & food fetch \\
\hline I 2 & $2 ; 1.6$ & $\backslash$ Essen $\mid$,holen & Essen holen & food fetch \\
\hline I 3 & $2 ; 1.6$ & 'Hände | ,waschen & Hände waschen & hands wash \\
\hline I 4 & $2 ; 1.9$ & $\backslash$ Tunne \machen & Tunnel machen & tunnel make \\
\hline I 5 & $2 ; 1.9$ & $\backslash$ Finger | ,putzen & Finger putzen & fingers clean \\
\hline
\end{tabular}

(d) Determiner + Noun combinations

\begin{tabular}{|c|c|c|c|c|}
\hline \# & Age & $\begin{array}{l}\text { Utterance } \\
\text { intonation }\end{array}$ & $\begin{array}{c}\text { Utterance } \\
\text { orthographic }\end{array}$ & Gloss \\
\hline I & $2 ; \mathrm{I} .5$ & ein $\mid \backslash$ Schornstein & ein Schornstein & a chimney \\
\hline 2 & $2 ; 1.6$ & \einer | \Gong & einer Waggon & a carriage \\
\hline 3 & 2 ; I.IO & \eine 'Kik & eine Keks & a cookie \\
\hline 4 & 2 ; I.IO & 'ein | ,Kirsche & ein Kirsche & a cherry \\
\hline 5 & 2 ; I.I I & 'ein |,Sock & ein Sock(en) & a sock \\
\hline 6 & 2 ; I. I I & 'ein ,Socken & ein Socken & a sock \\
\hline 7 & 2 ; I. I I & /ein \Huhn & ein Huhn & a chicken \\
\hline 8 & 2 ; I.I I & \viele | \Leute & viele Leute & many people \\
\hline 9 & 2 ; I.I 2 & \viele | \Kärtchen & viele Kärtchen & many cards-DIM \\
\hline IO & 2 ; I.I 2 & 'ein ,Brot & ein Brot & a bread \\
\hline I I & 2 ; I.I 2 & $\mathrm{n} \mid \backslash$ Vogel & ein Vogel & a bird \\
\hline 12 & 2 ; I.I 2 & die $\mid \backslash$ Zuge & die Zuge (=Züge) & the trains \\
\hline I 3 & 2 ; I.I 2 & 'ein ,Lok & ein Lok & a locomotive \\
\hline I 4 & $2 ; \mathrm{I} . \mathrm{I} 2$ & /das | 'Feuer \auto & das Feuerwehrauto & the fire-engine \\
\hline I 5 & 2 ; I.I 2 & 'ein | ,Rad & ein $\mathrm{Rad}$ & a wheel \\
\hline
\end{tabular}




\section{APPENDIX 3}

LEO'S TWO-WORD UTTERANCES AT 2;2

(a) Noun + Noun repetitions

\begin{tabular}{|c|c|c|c|c|}
\hline \# & Age & $\begin{array}{l}\text { Utterance } \\
\text { intonation }\end{array}$ & $\begin{array}{c}\text { Utterance } \\
\text { orthographic }\end{array}$ & Gloss \\
\hline I & $2 ; 2.0$ & $\backslash$ Salzstänge | \Salzstänge & Salzstängelэ & saltstick-DIM \\
\hline 2 & $2 ; 2.0$ & $\backslash \mathrm{Opa} \backslash \mathrm{Opa}$ & Opa & granddad \\
\hline 3 & $2 ; 2.0$ & $\backslash$ Berg $\mid \backslash$ Berg & Berg & mountain \\
\hline 4 & $2 ; 2.0$ & \Wasser | \Wasser & Wasser & water \\
\hline 5 & $2 ; 2.0$ & $\backslash$ Tunnel | \Tunnel & Tunnel & tunnel \\
\hline 6 & $2 ; 2.0$ & $/ \operatorname{Rad} \mid / \operatorname{Rad}$ & Rad & wheel \\
\hline 7 & $2 ; 2.0$ & 'Berg | -Berg & Berg & mountain \\
\hline 8 & $2 ; 2.0$ & $\backslash$ China $\mid \backslash$ China & China & China \\
\hline 9 & $2 ; 2 . I$ & $\backslash$ Rungen $\mid \backslash$ Rungen & Blumen & flowers \\
\hline IO & $2 ; 2 . I$ & $\backslash$ Feuerauto $\mid \backslash$ Feuerauto & Feuerwehrauto & fire engine \\
\hline I I & $2 ; 2 . \mathrm{I}$ & $\backslash$ Auto $\mid \backslash$ Auto & Auto & car \\
\hline I 2 & $2 ; 2 . \mathrm{I}$ & $\backslash$ Honig | \Honig & Honig & honey \\
\hline I 3 & $2 ; 2 . I$ & $\backslash$ Honigkeks | \Honigkeks & Honigkeks & honey buiscuit \\
\hline I 4 & $2 ; 2 . I$ & $\backslash$ Lampen $\mid \backslash$ Lampen & Lampen & lamps \\
\hline I 5 & $2 ; 2 . I$ & ,Hut | -Hut & Hund & $\operatorname{dog}$ \\
\hline
\end{tabular}

(b) Noun + Particle combinations

\begin{tabular}{|c|c|c|c|c|}
\hline$\#$ & Age & $\begin{array}{l}\text { Utterance } \\
\text { intonation }\end{array}$ & $\begin{array}{c}\text { Utterance } \\
\text { orthographic }\end{array}$ & Gloss \\
\hline I & $2 ; 2.0$ & \Salzstängle |,mit & Salzstängle mit & saltstick-DIM with \\
\hline 2 & $2 ; 2.0$ & Salzstängle ,drin & Salzstängle drin & saltstick-DIM inside \\
\hline 3 & $2 ; 2.0$ & $\backslash \mathrm{Opa}-\mathrm{mit}$ & Opa mit & grandpa with \\
\hline 4 & $2 ; 2.0$ & /Zug | ,ab & Zug ab & train off \\
\hline 5 & $2 ; 2.0$ & /Lok | \runter & Lok runter & locomotive down \\
\hline 6 & $2 ; 2.0$ & $\backslash$ Gurken | ,drin & Gurken drin & cucumbers inside \\
\hline 7 & $2 ; 2.0$ & $\backslash$ Gurken drin & Gurken drin & cucumbers inside \\
\hline 8 & $2 ; 2.0$ & Kelle hoch & Kelle hoch & signalling disc up \\
\hline 9 & $2 ; 2.1$ & $\backslash$ Autos | ,rüber & Autos rüber & cars over \\
\hline IO & $2 ; 2.1$ & $\backslash$ Feuer drin & Feuer drin & fire inside \\
\hline I I & $2 ; 2 . \mathrm{I}$ & $\backslash$ Rauch raus & Rauch raus & smoke out \\
\hline I 2 & $2 ; 2.2$ & $\backslash$ Karten | /weg & Karten weg & cards away \\
\hline I 3 & $2 ; 2.1$ & $\backslash$ Eisenbahn $\mid$, auf & Eisenbahn auf & train up/open \\
\hline I 4 & $2 ; 2.2$ & Wagen 'weg & Wagen weg & car away \\
\hline I 5 & $2 ; 2.2$ & $\backslash$ Kuchen auf & Kuchen auf & cake up \\
\hline
\end{tabular}


(c) Noun + Infinitive combinations

\begin{tabular}{rrlll}
\hline$\#$ & Age & \multicolumn{1}{c}{$\begin{array}{c}\text { Utterance } \\
\text { intonation }\end{array}$} & \multicolumn{1}{c}{$\begin{array}{c}\text { Utterance } \\
\text { orthographic }\end{array}$} & \multicolumn{1}{c}{ Gloss } \\
\hline I & $2 ; 2.0$ & $\backslash$ Tunnel | baun & Tunnel bauen & tunnel build \\
2 & $2 ; 2.0$ & $\backslash$ Brezel | ziehn & Brezel ziehen & pretzel pull \\
Orandpa drive \\
3 & $2 ; 2.0$ & $\backslash$ Opa fahrn & Bpagger bauen & digger build \\
4 & $2 ; 2.0$ & $\backslash$ Bagger baun & Tunnel bauen & tunnel build \\
5 & $2 ; 2.0$ & $\backslash$ Tunnel baun & Strasse machen & street make \\
6 & $2 ; 2.0$ & $\backslash$ Strasse machen & Tunnel bauen & tunnel build \\
7 & $2 ; 2.0$ & $\backslash$ Tunnel baun & Kuchen laden & cake load \\
8 & $2 ; 2.0$ & $\backslash$ Kuchen \laden & Schranke bauen & barrier build \\
9 & $2 ; 2.0$ & $\backslash$ Schranke baun & Elefant einkaufen & elephant shop \\
I0 & $2 ; 2.2$ & Ele $\backslash$ fant ein | kaufen & Elefant einkaufen & elephant shop \\
I I & $2 ; 2.2$ & Ele $\backslash$ fant | einkaufen & Zug bauen & train build \\
I2 & $2 ; 2.2$ & $\backslash$ Zug baun & Tunnel bauen & tunnel build \\
I3 & $2 ; 2.2$ & $\backslash$ Tunnel | baun & Kneten holen & playdoughs fetch \\
I4 & $2 ; 2.3$ & /Kneten | 'holen & Lok bauen & locomotive build \\
I5 & $2 ; 2.3$ & $\backslash$ Lok baun & &
\end{tabular}

(d) Determiner + Noun combinations

\begin{tabular}{|c|c|c|c|c|}
\hline \# & Age & $\begin{array}{l}\text { Utterance } \\
\text { intonation }\end{array}$ & $\begin{array}{c}\text { Utterance } \\
\text { orthographic }\end{array}$ & Gloss \\
\hline I & $2 ; 2.0$ & en $\backslash$ Ball & ein Ball & a ball \\
\hline 2 & $2 ; 2.0$ & ne | $\backslash$ Güterzug & eine Güterzug & a cargo-train \\
\hline 3 & $2 ; 2.0$ & ,ein $\mid \backslash Z u g$ & ein Zug & a train \\
\hline 4 & $2 ; 2.0$ & 'ein | ,Rad & ein $\operatorname{Rad}$ & a wheel \\
\hline 5 & $2 ; 2.0$ & der Vau \käfer & $\operatorname{der} \mathrm{V}+\mathrm{W}+\mathrm{Käfer}$ & the VW-beetle \\
\hline 6 & $2 ; 2.0$ & /e 'Kuh & eine Kuh & a cow \\
\hline 7 & $2 ; 2.0$ & $\backslash$ eie \ine & eine (Ros)ine & a raisin \\
\hline 8 & $2 ; 2.1$ & $\backslash$ eine Marge \rite & eine Margerite & a daisy \\
\hline 9 & $2 ; 2.1$ & eine \ine & eine (Apfel)sine & an orange \\
\hline Io & $2 ; 2.1$ & $\backslash$ eine $\mid \backslash$ Apfel & eine Apfel & an apple \\
\hline I I & $2 ; 2 . \mathrm{I}$ & ein $\backslash Z u g$ & ein Zug & a train \\
\hline 12 & $2 ; 2.2$ & $\mathrm{e} \backslash$ eine $\backslash$ Nuss & eine Nuss & a nut \\
\hline I 3 & $2 ; 2.2$ & $\wedge$ eine Nuss & eine Nuss & a nut \\
\hline I 4 & $2 ; 2.2$ & ^eine Nuss & eine Nuss & a nut \\
\hline I 5 & $2 ; 2.2$ & en $\backslash$ Kuchen & ein Kuchen & a cake \\
\hline
\end{tabular}




\section{APPENDIX 4}

LEO'S TWO-WORD UTTERANCES AT 2;3

(a) Noun + Noun repetitions

\begin{tabular}{|c|c|c|c|c|}
\hline \# & Age & $\begin{array}{l}\text { Utterance } \\
\text { intonation }\end{array}$ & $\begin{array}{l}\text { Utterance } \\
\text { orthographic }\end{array}$ & Gloss \\
\hline I & $2 ; 2.30$ & $\begin{array}{c}\backslash \text { Buchstaben } \mid \\
\backslash \text { Buchstaben }\end{array}$ & Buchstaben & letters \\
\hline 2 & $2 ; 2.30$ & $\backslash$ Brezeln $\backslash$ Brezeln & Brezeln & pretzels \\
\hline 3 & $2 ; 2.30$ & $\begin{array}{l}\text { Rasende } \backslash \text { Roland } \\
\text { rasen } \backslash \text { Roland }\end{array}$ & Rasender-Roland & $\begin{array}{l}\text { Racing-Roland } \\
\text { (name of train) }\end{array}$ \\
\hline 4 & $2 ; 2.30$ & $\wedge$ Heike $\mid \wedge$ Heike & Heike & $\begin{array}{l}\text { Heike } \\
\text { (proper name) }\end{array}$ \\
\hline 5 & $2 ; 2.30$ & $\begin{array}{l}\text { rasen } \backslash \text { Roland } \mid \text { rasen } \\
\backslash \text { Roland }\end{array}$ & Rasender-Roland & $\begin{array}{l}\text { Racing-Roland } \\
\text { (name of train) }\end{array}$ \\
\hline 6 & $2 ; 2.30$ & $\begin{array}{l}\text { rasen } \mid \backslash \text { Roland | rasen } \\
\backslash \text { Roland }\end{array}$ & Rasender-Roland & $\begin{array}{l}\text { Racing-Roland } \\
\text { (name of train) }\end{array}$ \\
\hline 7 & $2 ; 2.30$ & $\backslash$ Glocken | \Glocken & Glocken & bells \\
\hline 8 & $2 ; 2.30$ & $/$ Eis $\backslash$ Eis & Eis & ice cream \\
\hline 9 & $2 ; 2.30$ & -Eis $\mid$,Eis & Eis & ice cream \\
\hline IO & $2 ; 2.30$ & $\begin{array}{l}\backslash \text { Einkaufladen } \\
\backslash \text { Einkaufladen }^{1}\end{array}$ & Einkaufsladen & Shop \\
\hline I I & $2 ; 2.30$ & $\backslash$ Stieleis $\mid \backslash$ Stieleis & Stieleis & $\begin{array}{l}\text { ice cream on } \\
\text { a stick }\end{array}$ \\
\hline I 2 & $2 ; 3.01$ & $\begin{array}{l}\backslash \text { Schweinetrog } \mid \\
\backslash \text { Schweinetrog }\end{array}$ & Schweinetrog & pig trough \\
\hline I 3 & $2 ; 3.01$ & $\begin{array}{c}\text { Kapri } \backslash \text { olen } \mid \\
\text { Kapri } \backslash \text { olen }\end{array}$ & Kapriolen & Capers \\
\hline I 4 & $2 ; 3.01$ & $\backslash$ Schaf $\mid \backslash$ Schaf & Schaf & Sheep \\
\hline I 5 & $2 ; 3.01$ & $\backslash$ Mittag $\mid \backslash$ Mittag & Mittag & Midday \\
\hline
\end{tabular}

[I] It is clear from the context that "Einkauf(s)laden" is a compound noun, not a V+N. 
(b) Noun + Particle combinations

\begin{tabular}{|c|c|c|c|c|}
\hline \# & Age & $\begin{array}{l}\text { Utterance } \\
\text { intonation }\end{array}$ & $\begin{array}{c}\text { Utterance } \\
\text { orthographic }\end{array}$ & Gloss \\
\hline I & $2 ; 2.30$ & 'Tasse ,rum & Tasse rum & cup around/over \\
\hline 2 & $2 ; 2.30$ & /oko \lade | ,dran & Schokolade dran & chocolate on \\
\hline 3 & $2 ; 2.30$ & $\wedge$ Nuss drauf & Nuss drauf & nut on \\
\hline 4 & $2 ; 2.30$ & Poli \zeiauto | hin & Polizeiauto hin & police car towards \\
\hline 5 & $2 ; 3.0$ & $\wedge$ Äpfel runter & Äpfel runter & apples down \\
\hline 6 & $2 ; 3.0$ & $\backslash$ Äpfel runter & Äpfel runter & apples down \\
\hline 7 & $2 ; 3.0$ & $\wedge$ Leiter runter & Leiter runter & ladder down \\
\hline 8 & $2 ; 3.0$ & Kette | 'hin & (Berg)Kette hin & mountain ridge towards \\
\hline 9 & $2 ; 3 \cdot I$ & $\wedge$ Papa mit & Papa mit & daddy with \\
\hline IO & $2 ; 3 \cdot 1$ & $\backslash$ Papa mit & Papa mit & daddy with \\
\hline I I & $2 ; 3 \cdot 1$ & $\wedge$ Brille auf & Brille auf & glasses on \\
\hline 12 & $2 ; 3 \cdot I$ & $\backslash$ Papa mit & Papa mit & daddy with \\
\hline I 3 & $2 ; 3 \cdot 1$ & $\backslash$ Papa mit & Papa mit & daddy with \\
\hline I 4 & $2 ; 3 \cdot I$ & $\wedge$ Papa mit & Papa mit & daddy with \\
\hline I 5 & $2 ; 3 \cdot I$ & $\backslash$ Papa mit & Papa mit & daddy with \\
\hline
\end{tabular}


(c) Noun + Infinitive combination

\begin{tabular}{|c|c|c|c|c|}
\hline \# & Age & $\begin{array}{l}\text { Utterance } \\
\text { intonation }\end{array}$ & $\begin{array}{c}\text { Utterance } \\
\text { orthographic }\end{array}$ & Gloss \\
\hline I & $2 ; 2.30$ & $\begin{array}{l}\wedge \text { Plätzchen | } \\
\text {,angucken }\end{array}$ & Plätzchen angucken & cookies look-at \\
\hline 2 & $2 ; 2.30$ & $\begin{array}{l}\backslash \text { Plätzchen } \\
\text {,angucken }\end{array}$ & Plätzchen angucken & cookies look-at \\
\hline 3 & $2 ; 2.30$ & $\wedge$ Kekse ,angucken & Kekse angucken & cookies look-at \\
\hline 4 & $2 ; 2.30$ & $\backslash$ Plätzchen angucken & Plätzchen angucken & cookies look-at \\
\hline 5 & $2 ; 2.30$ & $\backslash$ Plätzchen angucken & Plätzchen angucken & cookies look-at \\
\hline 6 & $2 ; 2.30$ & Augen \zuhalten & Augen zuhalten & eyes hold-close \\
\hline 7 & $2 ; 2.30$ & Augen \zuhalten & Augen zuhalten & eyes hold-close \\
\hline 8 & $2 ; 2.30$ & $\begin{array}{l}\backslash \text { Kochbuch } \mid \\
\mid \text { angucken }\end{array}$ & Kochbuch angucken & cookbook look-at \\
\hline 9 & $2 ; 2.30$ & $\begin{array}{l}\backslash \text { Häuserchen } \mid \\
\backslash \text { anbaun }\end{array}$ & Häuserchen anbauen & $\begin{array}{l}\text { houses-DIM } \\
\text { build-at }\end{array}$ \\
\hline IO & $2 ; 2.30$ & Augen \zuhalten & Augen zuhalten & eyes hold-close \\
\hline I I & $2 ; 2.30$ & $\backslash Z$ üge einkau $\mid$ fn & Züge einkaufen & trains buy \\
\hline I 2 & $2 ; 2.30$ & $\backslash Z$ üge einkaufen & Züge einkaufen & trains buy \\
\hline I 3 & $2 ; 2.30$ & $\begin{array}{l}\text { e } \wedge \text { Brücke hoch, } \\
\text { kommen }\end{array}$ & Brücke hochkommen & bridge come-up \\
\hline I 4 & $2 ; 2.30$ & $\begin{array}{l}\wedge \text { Glockenturm | } \\
\text { umfalln }\end{array}$ & $\begin{array}{l}\text { Glockenturm } \\
\text { umfallen }\end{array}$ & $\begin{array}{l}\text { belltower } \\
\text { fall-over }\end{array}$ \\
\hline I 5 & $2 ; 2.30$ & Fi\gun holen & Figuren holen & $\begin{array}{l}\text { (toy)-figures } \\
\text { fetch }\end{array}$ \\
\hline
\end{tabular}


(d) Determiner + Noun combinations

\begin{tabular}{|c|c|c|c|c|}
\hline$\#$ & Age & $\begin{array}{l}\text { Utterance } \\
\text { intonation }\end{array}$ & $\begin{array}{l}\text { Utterance } \\
\text { orthographic }\end{array}$ & Gloss \\
\hline I & $2 ; 2.30$ & ein \Tannenbaum & ein Tannenbaum & a fir tree \\
\hline 2 & $2 ; 2.30$ & -die |,Plä \tzchen & die Plätzchen & the cookies \\
\hline 3 & $2 ; 2.30$ & die $\backslash$ Solvejg & die Solvejg & $\begin{array}{l}\text { the Solvejg } \\
\text { (proper name) }\end{array}$ \\
\hline 4 & $2 ; 2.30$ & ein $\backslash$ Pferd & ein Pferd & a horse \\
\hline 5 & $2 ; 2.30$ & /ein \Bär & ein Bär & a bear \\
\hline 6 & $2 ; 2.30$ & ein $\backslash$ Pringer & ein Springer & a jumper \\
\hline 7 & $2 ; 2.30$ & ein $\backslash$ Bär & ein Bär & a bear \\
\hline 8 & $2 ; 2.30$ & ein \Hörnchen & ein Hörnchen & a croissant \\
\hline 9 & $2 ; 2.30$ & /ein \Hörnchen & ein Hörnchen & a croissant \\
\hline IO & $2 ; 2.30$ & ein $\backslash$ Kekse & ein Kekse & a cookies \\
\hline I I & $2 ; 2.30$ & /ein \Butterkeks & ein Butterkeks & a butter-cookie \\
\hline I 2 & $2 ; 2.30$ & ein $\backslash$ Butterkeks & ein Butterkeks & a butter-cookie \\
\hline I 3 & $2 ; 2.30$ & keine $\backslash$ Eisenbahn & keine Eisenbahn & $\begin{array}{l}\text { NEG-the train } \\
\text { 'no train' }\end{array}$ \\
\hline I 4 & $2 ; 2.30$ & ein $\backslash$ Mond & ein Mond & a moon \\
\hline I 5 & $2 ; 2.30$ & 'keine Ge $\backslash$ sichter & keine Gesichter & $\begin{array}{l}\text { NEG-the faces } \\
\text { 'no faces' }\end{array}$ \\
\hline
\end{tabular}

